\title{
Dielectric Properties of Graded and Non-Graded InGaN/GaN MQWs
}

\author{
Ahmet Kürşat BİLGİLi ${ }^{1 *}$, Mustafa Kemal ÖZTÜRK², Süleyman ÖZÇELİK ${ }^{3}$, \\ Adem TATAROĞLU ${ }^{4}$
}

\begin{abstract}
In this study, dielectric properties of graded and non-graded InGaN/GaN multi quantum wells (MQWs), grown on sapphire $\left(\mathrm{Al}_{2} \mathrm{O}_{3}\right)$ wafer by Metal Organic Chemical Vapor Deposition (MOCVD) technique, are investigated. In order to notice graded layer effect on characteristics of MQWs some of GaN layers are grown by doping In atoms. Dielectric function of films are determined by Swanepoel envelope method. Real and imaginer dielectric coefficient of the films are calculated by using refraction index and extinction coefficient. Differences in refraction index values are discussed for graded and non-graded samples. During determination of dielectric function variations of complex and imaginer dielectric coefficients with photon energy are shown for both samples
\end{abstract}

Keywords: Swanepoel envelope method, graded, non-graded, InGaN.

\section{Dereceli ve derecesiz InGaN/GaN MQW'lerin dielektrik özellikleri}

\section{$\ddot{O ̈ z}$}

$\mathrm{Bu}$ çalışmada, Metal organik kimyasal buhar biriktirme(MOCVD) metoduyla safïr $\left(\mathrm{Al}_{2} \mathrm{O}_{3}\right)$ üzerine büyütülen dereceli ve derecesiz InGaN/GaN MQW'lerin dielektrik özellikleri incelendi. Dereceli tabakanın MQW'nin karakteristikleri üzerine etkisini fark edebilmek için bazı GaN tabakalar In aşılanarak büyütülmüştür. Filmlerin dielektrik fonksiyonu Swanepoel zarf metodu ile belirlenmiştir. Filmlerin gerçel ve imajiner dielektrik katsayıları, kırılma indisi ve soğurma katsayıları kullanılarak hesaplanmıştır. Dereceli ve derecesiz örnekler için kırılma indisi değerlerindeki farklılıklar tartışılmıştır. Dielektrik fonksiyonunun belirlenmesi sırasında, her iki numune için kompleks ve imajiner dielektrik sabitlerinin foton enerjisine göre değişimleri gösterilmiştir.

Anahtar Kelimeler: Swanepoel zarf metodu, dereceli, derecesiz, InGaN.

\footnotetext{
${ }^{1}$ Gazi University, Physics Department, Ankara, Turkey, ahmet.kursat.bilgili@gazi.edu.tr

${ }^{2}$ Gazi University, Photonics Research and application center, Ankara, Turkey, mozturk@gazi.edu.tr

${ }^{3}$ Gazi University, Photonics Research and application center, Ankara, Turkey, sozcelik@gazi.edu.tr

${ }^{4}$ Gazi University, Physics Department, Ankara, Turkey, ademt@gazi.edu.tr
} 


\section{Introduction}

Compounds such as $\mathrm{GaN}$ and $\mathrm{InGaN}$ formed by nitrite based semiconductors are taking attention since the beginning of ninetees. During growth of GaN layer on sapphire, because of lattice mismatch and the difference between thermal expansion coefficients, defects such as cracks may occur. These defects affects the performance of the device in a bad way but devices formed by nitrite based semiconductors performs well at high temperature and frequency although they have such defects. They are prefered because of this property (Williams et al., 1969).

Today optical thin films play major role in directing light (Willardson et al., 1978). They are used in defence industry, solar cells, high electron mobility transistors and medicine (Straussn et al., 1977., Kroger et al., 1977). In parallel to technological advance, structure of these optical equipments becomes more complex. In order to gain performance desired from optical equipments, applications in optics subject becomes more important. Before making an optical modelling, to have knowledge on optical properties of used materials is also important. Optical properties of thin films forms a research field among classical optics, electrodynamics, solid state physics and quantum mechanics (Gu et al., 1975).

To calculate thickness and optical constants of thin films dependent on wavelength, is important in terms of both basic knowledge and technological development. Even a small change in refraction index makes serious shift in spectral response (reflection and transmission) of optical components of thin films. For this reason, accuracy of complex refraction index and thickness is important in terms of production of optical components successfully (Selim et al., 1977., Anthony et al., 1985). By the help of these parameters mentioned parameters will be calculated; optical energy band gap, defect levels, phonon and plasm frequencies can be determined (Chu et al., 1985). Bilgili et al. determined optical properties of InGaN/GaN MQWs in an earlier study. In this study, dielectric properties of samples are investigated in the light of reference (Bilgili et al., 2019). By the help of optical constants gained from Swanepoel envelope method (1983), dielectric coefficients are calculated.

\section{Experimental details}

InGaN/GaN MQWs are grown on sapphire wafer by MOCVD as In graded and non-graded structures. Samples are cleaned under $\mathrm{H}_{2}$ atmosphere for 10 minutes at $1100{ }^{\circ} \mathrm{C}$ before epitaxial films are grown. After cleaning procedure, growth operation started by nucleation GaN layer at $575^{\circ} \mathrm{C}$. During growth, TMGa flux ratio is adjusted as $10 \mathrm{sccm}, \mathrm{NH}_{3}$ flux ratio is adjusted as $1500 \mathrm{sccm}$ and pressure is adjusted as 200 mbars. This nucleation layer has a thickness of $10 \mathrm{~nm}$. After growth of nucleation layer, growth of GaN buffer layer started at $1070^{\circ} \mathrm{C}$. This $\mathrm{GaN}$ buffer layer is grown with 
$15 \mathrm{sccm}$ flux ratio TMGa, $1800 \mathrm{sccm}$ flux ratio $\mathrm{NH}_{3}$ and 200 mbars pressure conditions. Thickness of GaN buffer layer is $1.6 \mu \mathrm{m}$. Growth operation continued by turning on $\mathrm{SiH}_{4}$ source. $\mathrm{SiH}_{4}$ source helps growth of n-type GaN layer. In MOCVD SiH 4 is diluted. Flux ratio of $\mathrm{SiH}_{4}$ source is $10 \mathrm{sccm}$. Graded and non-graded active layers are grown at $745-760^{\circ} \mathrm{C}$ with $75 \mathrm{sccm}$ In flux ratio. While the first sample has InGaN graded layer thickness of $20 \mathrm{~nm}$ and $200 \mathrm{~nm}$, second sample has an nongraded InGaN layer thickness of $220 \mathrm{~nm}$. Active layers are grown between n-type GaN and p- type InGaN layers with a thickness of $1.9 \mu \mathrm{m}$. p-type InGaN layer is grown by using $\mathrm{Mg}$ doping source. Flux ratio of this source is $35 \mathrm{sccm}$. During growth of InGaN layer other sources are kept in off position. To maintain more doping $\mathrm{Mg}$ source flux ratio is adjusted as $40 \mathrm{sccm}$. By making In flux ratio continuous forbidden energy band gap is gained as graded. In Figure.1 schematic diagrams of graded and non-graded InGaN/GaN MQWs can be seen.
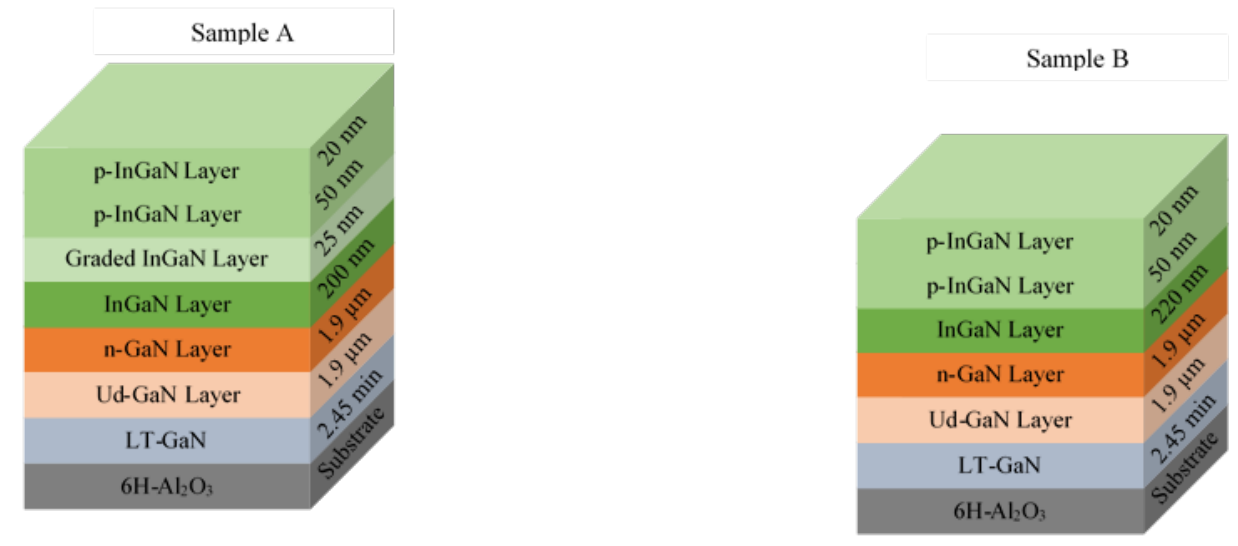

Figure.1 Schematic diagrams of graded and non-graded InGaN/GaN MQWs

\section{Results and Discussion}

In Swanepoel method, optical constants of mono layer or multi layer thin films grown on a transparent wafer can be determined by analising transmission plot. Heaven's book (Heavens et al., 1965) is a good reference on optical properties of thin films. Transmission spectras of the samples in this study are given in reference (Bilgili et al., 2019). In this reference refraction and extinction coefficients of samples are determined from Swanepoel envelope method. Here in Figure 2 only refraction index and extinction coefficient versus wavelength plots are repeated. 
a)

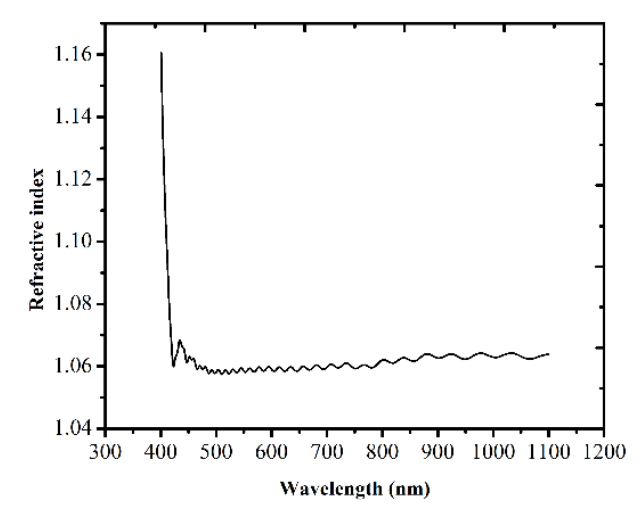

c)

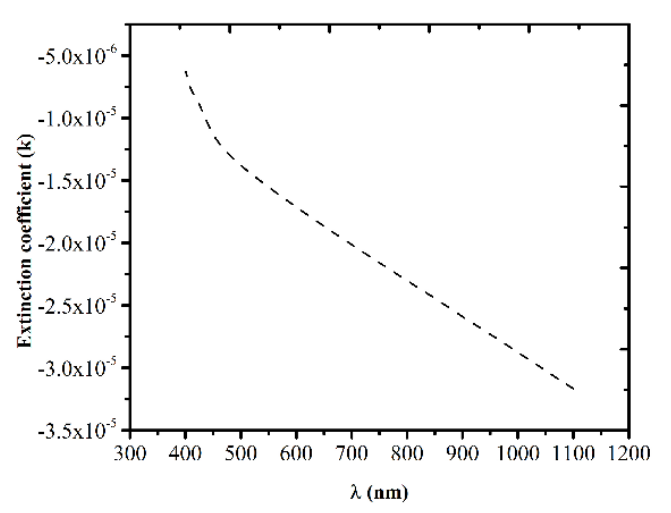

b)

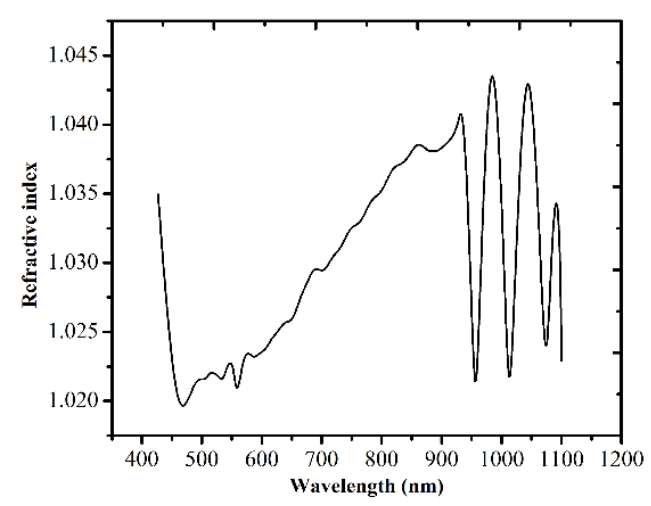

d)

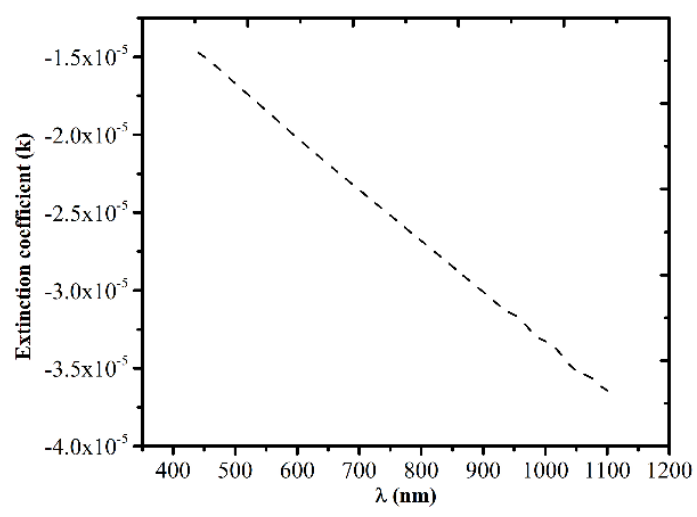

Figure.2 Refractive index and extinction coefficient variations versus wavelength for (a),(c) graded and (b), (d) non-graded InGaN/GaN MQWs[12].

As can be seen in Figure.2 (a) and (b) there is great difference in variations of refractive indexes for graded and non-graded samples. Variation of refractive index for graded layer is more smooth. This is also related with interatomic spaces. There is almost no difference in variation of extinction coefficients for both samples. Negative extinction coefficient implies that there is reflection.

If $n_{1}$ and $n_{2}$ are two refraction index values corresponding to $\lambda_{1}$ and $\lambda_{2}$ which are consecutive wavelengths for maximum and minimum, thickness can be calculated by equation (1). Thickness values in this study are calculated with a different plotting method and results are found in accordance with reference (Bilgili et al., 2019).

$$
\begin{aligned}
& d=\frac{\lambda_{1} \lambda_{2}}{2\left(\lambda_{1} n_{2}-\lambda_{2} n_{1}\right)} \\
& 2 n d=\left(m_{1}+l / 2\right) \lambda, \quad l=0,1,2,3 \ldots . . \\
& l / 2=2 d(n / \lambda)-m_{1}
\end{aligned}
$$


For all extramum points this calculation should be made and mean values for $\mathrm{d}$ should be calculated but equation (1) is too sensitive for mistakes during calculation of refraction index. In the calculations made by using this equation, a dispersion especially broadening of fringes at high wavelengths can cause deflections in thickness calculation. As a general rule, thickness values found for the last two maximas should be included in mean value calculation. By using $\mathrm{d}$ and $\mathrm{n}$ value gained from this thickness calculation $\mathrm{m}$ value representing degree of extramum points in equation (1) can be found. For every wavelength, $\mathrm{d}_{2}$ thickness value can be determined by using $\mathrm{n}_{1}$ value by taking full or half value of $\mathrm{m}$ in equation (1).

But $\mathrm{m}$ and $\mathrm{d}$ values can be calculated more sensitively by using graphic method as shown in Figure.3. If degree number is called as $m_{1}$ for the first extramum point equation (1) can be written as in equation (2) for extramum points of the spectra (Haochen et al., 2021).
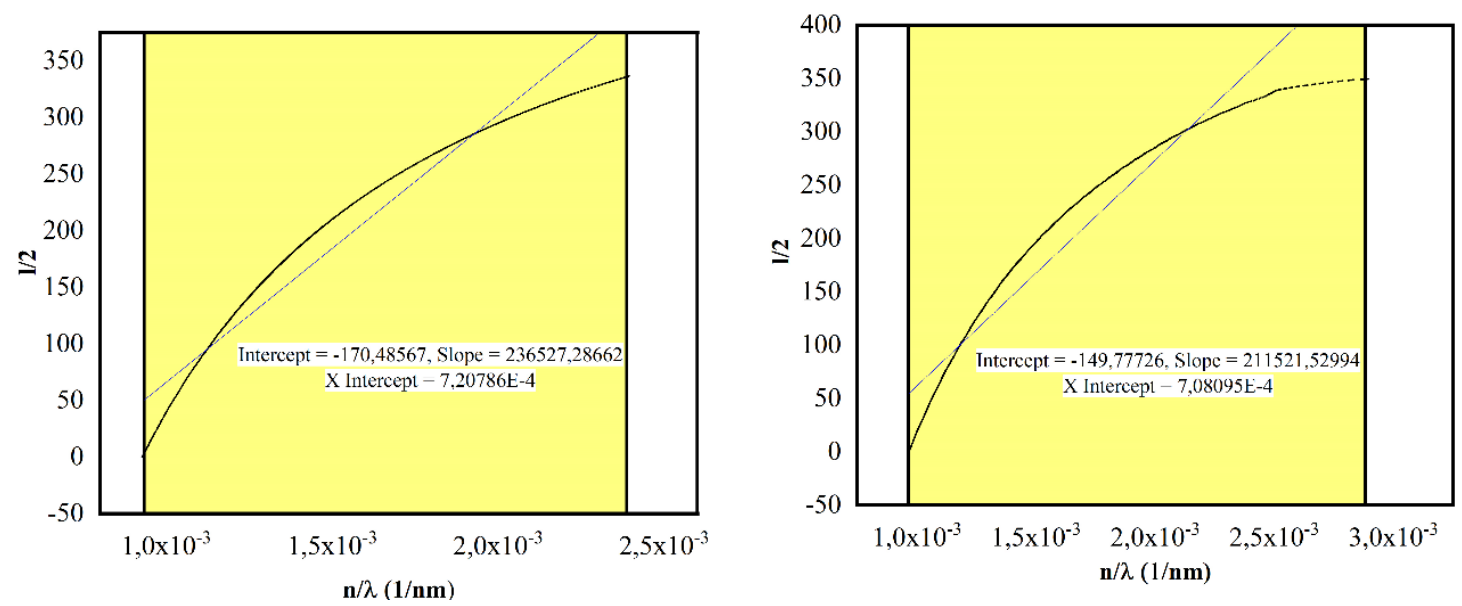

Figure. $3 \mathrm{n} / \lambda$ versus $1 / 2$ plots for film thicknesses.

By using the plot in Figure. 4 if $1 / 2$ versus $n / \lambda$ is plotted, slope of this plot gives $2 d$ value and y axis intercept gives $\mathrm{m}_{1}$ value (Rogalski., 2002).

Dielectric coefficient can also be calculated by using optical parameters. Dielectric coefficient is defined as $\varepsilon=\varepsilon_{1}+\mathrm{i} \varepsilon_{2}$ that is, real and imaginer parts of complex dielectric function. This situation is explained as follows (Fairballs et al., 1997).

$$
\begin{gathered}
\varepsilon_{1}=n^{2}-k^{2} \\
\varepsilon_{2}=2 n k
\end{gathered}
$$


a)

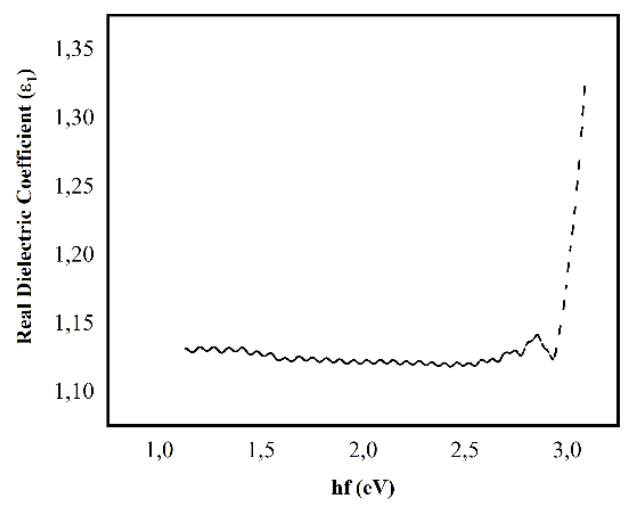

c)

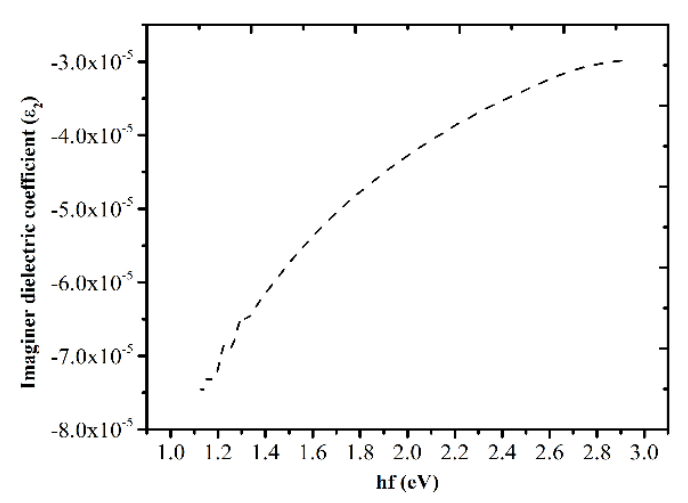

b)

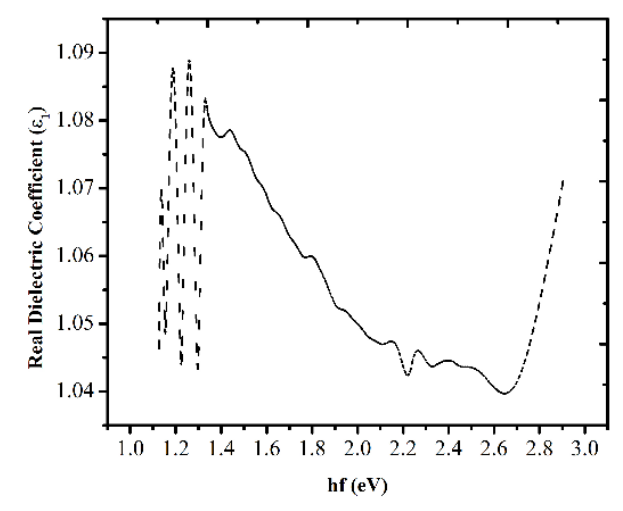

d)

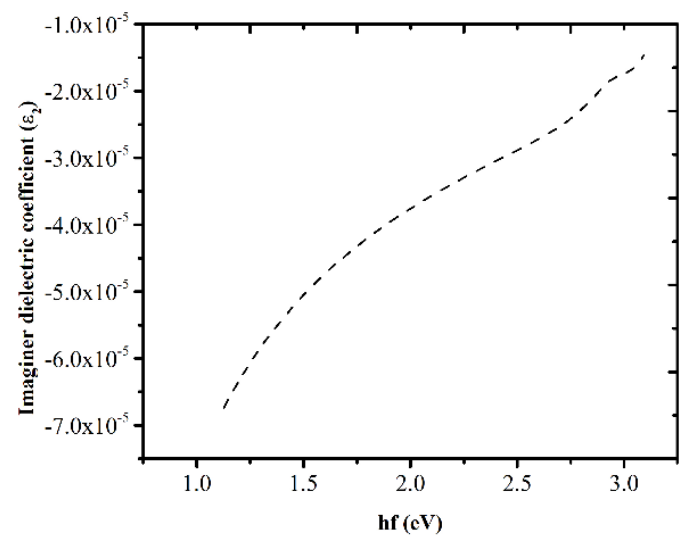

Figure.4 Real and imaginer dielectric functions dependent on energy.

Dielectric dependency is shown in Figure.4. Optical dielectric coefficient is calculated for InGaN/GaN MQWs. Variation of complex and imaginer dielectric coefficients with photon energy is shown. According to Figure.4 (a) and (b) it is noticed that being non-graded or graded effects real dielectric coefficient. But in Figure.4 (c) and (d) it can be seen that absorbtion starts about $1 \mathrm{eV}$ for both samples. This means that being graded or non-graded does not effect imaginer dielectric function (Kars et al., 2017).

\section{Conclusion}

In this study dielectric properties of graded and non-graded InGaN/GaN MQWs are investigated. Swanepoel envelope method is employed on transmission spectra. By using graphic method, thickness of films are determined as 1.0050 and $1.0150 \mathrm{~nm}$ approximately. Real and imaginer dielectric coefficients are also determined and shown on Figure.5. As a result of this study, being graded improves optical properties also it helps conductivity. On the other hand, being graded or 
non-graded does not effect some properties such as extinction coefficient and imaginer dielectric function. Refractive index variations shows fluctiative behaviour for graded sample but, in nongraded sample variation of refractive index versus wavelength is almost smooth. This behaviour may be attributed to inhomogeneous structure of graded layers along the sample. Also variation of real and imaginer dielectric coefficients versus photon energy are symmetric to refractive index variations. This may be because of similarities in mathematical functions used to determine these two parameters. Real dielectric coefficient values variate between nearly 1.04 and 1.09 for both samples. Imaginer dielectric coefficients change in the range of -8 and $-1\left(\times 10^{-5}\right)$.

\section{Acknowledgements}

This work was supported by Presidency Strategy and Budget Directorate (Grant Number: 2016K121220).

\section{Authors' Contributions}

All authors contributed equally to the study.

\section{Statement of Conflicts of Interest}

There is no conflict of interest between the authors.

\section{Statement of Research and Publication Ethics}

The author declares that this study complies with Research and Publication Ethics.

\section{References}

Williams M.G., Tomlinson R. D., Hampshire M. J. (1969). X-ray Determination of the Lattice Parameters and Thermal Expansion of Cadmium Telluride in the Temperature Range 20-420oC. Solid State Commun. 7, (24) : 1831-1832.

Willardson R. K., Beer A. C. (1978). Cadmium Telluride. Semiconductor and Semimetals. 13, 115

Straussn A.J. (1977). Physical Properties of CdTe. Rev. Phys. Appl. 12, (2) : 167-184

Kroger F. A. (1977). The Defect Structure of CdTe. Rev. Phys. Appl. 12 ,(2) : 205- 210.

Gu J., Kitahara T., Kawakami K., Sakaguchi T. (1975). Ohmic Contact and Impurity Conduction in p-doped CdTe. J. Appl. Phys. 46, (3) : 1184-1185.

Selim F. A., Kroger F. A. (1977). The Defect Structure of Phosphorus-Doped CdTe. J. Electrochem. Soc. $124,(3): 401-408$. 
Anthony T. C., Fahrenbruch A. L., Peters M. G., Bube R. H. (1985). Electrical Properties of CdTe Films and Junctions. J. Appl. Phys. 57,(2) : 400-41.

Chu T. L., Chu S. S., Firszt F., Naseem H. A., Stawski R. (1985). Deposition and Characterization of p-type Cadmium Telluride Films. J. Appl. Phys. 58,(3) : 1349-1355.

Heavens O. S. (1965). Optical Properties of Thin Solid Films. DoverPublications, New York. pg. 51.

Rogalski A. (2002). Infrared Detectors: An Overview. Infrared Phys. and Technol. 43: 187-210.

Babonas G. A., Bendoryus R.A., Shileika A. Y. (1971). Photoluminescence of CdTe under hydrostatic pressure. Sov. Phys. Semicond. 5:392.

Bilgili A.K., Akpınar Ö., Öztürk M.K. (2019). A detailed study on optical properties of InGaN/GaN/Al ${ }_{2} \mathrm{O}_{3}$ multi quantum wells. J Mater Sci: Mater Electron. 30, 10391-10398

Haochen Z., Chen H., Kang S., Huabin Y., Chong X., Danhao W., Zhongling L., Haiding S. (2021). Compositionally graded III-nitride alloys: building blocks for efficient ultraviolet optoelectronics and power electronics. Reports on Progress in Physics. 84044401

Fairbanks E., Gates M. (1997). Adaptation of Thin Film PV Technology For Use Space. Twenty sixth IEEE PV Specialist Conference Anaheim, CA.

Kars D. İ., Ozturk M. K., Çörekçi S., Tamer M., Bas Y., Özçelik S., Özbay E. (2017). Microstructural Analysis with Graded and Non-Graded Indium in InGaN Solar Cell. Journal of Nanoelectronics and Optoelectronics. vol.12, no.2, pp.109-117, 2017 